\title{
Life Cycle Assessment of Spent Sulfuric Acid from Lead-acid Traction Battery in Thailand
}

\author{
Intang K., Khaodhiar S., and Attaphong C.
}

\begin{abstract}
Recently, especially from 2015 to 2017, Thailand produced waste of lead-acid batteries (LABs) around 11,000 tons/year on an average which traction battery accounted for around $44 \%$ or 4,800 tons/year. It was estimated that $16 \%$ of spent LABs was considered as improper management. According to literature reviews, $22 \%$ by weight of LABs is an electrolyte which is sulfuric acid. Sulfuric acid used in the battery is a strong acid with $\mathrm{pH}$ lower than 2 . A leakage of sulfuric acid during disassembling or battery cell transportation can lead to environmental impact and ecotoxicity. A primary goal of this study is to assess the environmental impact of spent sulfuric acid from expired traction battery with and without treatment before discharge. A material flow analysis illustrated a quantity of traction battery used to calculate the amount of spent sulfuric acid. The highest total amount of spent sulfuric acid (which was 1,808 tons/year from 1,299 tons/year of traction batteries and 509 tons/year of improper management) was found in 2016. These most massive quantities were used to evaluate the impact on each scenario. The result showed that directly discharged spent sulfuric acid caused higher environmental impact load than treated one. Spent sulfuric acid played a significant role in the impact potentials. Marine aquatic ecotoxicity had the greatest impact compared to the other categories. The assessment of scenario comparison assured that pH adjustment of spent sulfuric acid was able to alleviate environmental impacts for expired battery management.
\end{abstract}

Index Terms - Lead-acid battery, sulfuric acid, material flow analysis, life cycle assessment.

\section{INTRODUCTION}

During 2015 - 2017, Industrial Waste Management Division, Department of Industrial Works, reported the amount of spent batteries and accumulators. It is estimated that more than 10,000 tons were generated. Over $88 \%$ are Lead-Acid batteries (LABs) because they are an affordable and efficient power sources. As a result of a LABs' growth, the main use of these batteries is in vehicles and electric equipment. According to the Basel convention and Hazardous Substance Act B.E. 2535 (1992), LABs are considered as hazardous

Manuscript received April 29, 2019; revised July 2, 2019. This work was supported in part by the Scholarship from the Graduate School, Chulalongkorn University to commemorate the 72nd anniversary of his Majesty King Bhumibol Adulyadej is gratefully acknowledged.

Intang K. is with the Department of Environmental Engineering, Faculty of Engineering, Chulalongkorn University, Bangkok, Thailand (e-mail: kanokpraew.i@gmail.com).

Khaodhiar S. is with Research Program of Industrial Waste Management - Policies and Practices, Center of Excellence on Hazardous Substance Management (HSM), Chulalongkorn University, Bangkok, Thailand (e-mail: sutha.k@chula.ac.th).

Attaphong C. is with the Department of Civil Engineering, Faculty of Engineering, King Mongkut's Institute of Technology Ladkrabang, Bangkok, Thailand (e-mail: chodchanok.at@kmitl.ac.th). waste. Due to the main components (i.e., lead, sulfuric acid, and plastic), they are corrosive, reactive and toxic. According to the latest information, around $84 \%$ of LABs have been recycling in Thailand [1]. All types of LABs are composed of lead, sulfuric acid, and plastic as $63 \%, 22 \%$, and $15 \%$ by weight, respectively [2].

Traction or deep cycle batteries are widely used in marine applications, golf carts, forklift trucks, for storing energy generated by photovoltaic cells and wind turbines and for back-up power supplies (WHO, 2017). The traction batteries' size is larger than typical ones. In 2015-2017, the number of imported traction batteries was almost half on automotive batteries in Thailand.

After dismantling, lead and plastic are recycled into new battery's raw materials. Lead and its compounds are metal in solid forms which have lower potentiality of exposure and dispersion than sulfuric acid. Concentrated sulfuric acid is an electrolyte solution that is extremely corrosive and cause serious chemical burning. Moreover, it might be contaminated with various heavy metals such as lead and copper resulting in permanent adverse human health effects and significant learning disabilities in children. Most previous studies focus on lead and plastic recycling and recovery. However, there is limited research on spent sulfuric acid handling.

These days, spent sulfuric acid management is handled by LAB's manufacturers and authorized waste processor with an appropriated method. Nonetheless, the waste collectors probably have done by inappropriate management, which spent sulfuric acid was directly discharged to the environment. Hence, we focus on estimating spent sulfuric acid from LABs quantities in Thailand from 2015 to 2017 due to the latest official data from the National Organization. The difference of the total amount of spent sulfuric acid per year and the amount in management system (both formal and informal methods) results in the estimated amount of stock spent sulfuric acid. This paper examined both the quantity and impact of spent sulfuric acid.

\section{METHODOLOGY}

\section{A. Material Flow Analysis (MFA)}

This part of the study aims to determine and quantify the amount of spent sulfuric acid from traction batteries. There were 2 layers of diagram that was created: those lead-acid batteries as a good and those sulfuric acids as a substance.

\section{1) System boundary definition}

A system boundary in this study is Thailand and a temporal scope is defined as the time period from 2015 to 2017. Based 
on current management and a mass component of LABs, an electrolyte which is sulfuric acid to estimate total amount of spent sulfuric acid from traction batteries has been focused. According to the basic specifications, traction batteries used in this study has 2-volt and approximately 30-kilogram battery cells. It should be noted that metals and plastic cases are not considered in this paper.

Material flow analysis (MFA) is a systematic assessment of the flows and stocks of materials within a system defined by space and time [3]. Many studied uses MFA as a tool for estimating material quantity, phase and a significant change in flows. In order to create the material flow diagrams using STAN version 2.6.801, users must design processes and systems, and then complete the input and output flow of each process.

Material flows are divided into 3 stages: distribution of LABs, consumption and waste management. The pre-consumption refers to imported, exported and domestic production of new LABs. The consumption considers stock material that is a difference between input and output flows. The waste management mentions spent battery management via authorized waste processors and others.

\section{2) Data collection and sources}

This study used both primary data from laboratory and secondary data from the nation report. Amount of spent LABs recycled by waste processors was reported by the Department of Industrial Work. The imported-exported amount and nationwide production are obtained from the Customs Department and Office of Industrial Economics, respectively. As a consequence of the data availability, flows were calculated in different ways: direct from database, reasonable assumption based on imported amount and analytic from literatures.

To estimate sulfuric acid's quantity, LABs are divided into 2 types; automotive and traction batteries. However, there is no available data of the proportion for each type. Research assumption is that the proportion of imported LABs and national consumption between the automotive battery and traction battery are identical. The proper and improper management of spent LABs accounted for $84 \%$ and $16 \%$, respectively. A rest of amount LABs was assumed as stock in system boundary.

\section{B. Life Cycle Assessment (LCA)}

Life cycle assessment (LCA) is used as a tool that analyses and provides the potential environmental impact of spent sulfuric acid. According to ISO 14040 and 14044, there are 4 steps of LCA: goal and scope definition, inventory analysis, life cycle impact assessment, and life cycle interpretation. Owing to data restrictions, LCA was achieved by the data from the experiment and material flow analysis, and the only amount of spent sulfuric acid from traction battery was estimated within the system boundary of "gate-to-gate"; looking at only one process in the whole production chain. Only waste management phase was focused in this study. A SimaPro version 8.3 was used as LCA software. The database was Ecoinvent and primary data from the experiments which are concentrations of elements ( $\mathrm{Al}, \mathrm{Cu}, \mathrm{Fe}, \mathrm{Mg}, \mathrm{Pb}$, and $\mathrm{Zn}$ ) in ppm and concentrations of spent sulfuric acid in molar.
The spent sulfuric from traction battery contained 28.04 ppm of $\mathrm{Mg}, 17.99 \mathrm{ppm}$ of $\mathrm{Al}, 14.93 \mathrm{ppm}$ of Fe, $7.71 \mathrm{ppm}$ of $\mathrm{Zn}, 3.46 \mathrm{ppm}$ of $\mathrm{Pb}$, and $3.24 \mathrm{ppm}$ of $\mathrm{Cu}$.

The aims of this study were to evaluate the environmental impacts of spent sulfuric acid and to compare the impacts between untreated and treated spent sulfuric acid by $\mathrm{pH}$ adjustment with lime. Only the largest quantity of traction battery and improper management per year was assessed with LCA as the most probable impact. The functional unit was 1,808-ton spent sulfuric acid from LABs.

There were 3 scenarios which were 1) base case; $84 \%$ of spent sulfuric acid was treated by $\mathrm{pH}$ adjustment 2) worst case; all spent sulfuric acid was allocated to Do-nothing option (directly discharged) and 3) best case; all spent sulfuric acid was neutralized before discharge. These scenarios did not take economical and technical aspects into account.

For the impact assessment, the CML-baseline V3.04 was used as the LCA method [4]. There are 10 impact categories: abiotic depletion, acidification, eutrophication, fresh water aquatic ecotoxicity, global warming, human toxicity, marine aquatic ecotoxicity, ozone layer depletion, photochemical oxidation, and terrestrial ecotoxicity.

\section{RESULT AND DISCUSSION}

\section{A. Inventory Data}

There are 3 phases in the boundary: distribution of LABs, consumption and waste management. This study emphasizes on waste management phase of traction batteries. The amount of spent sulfuric acid was $22 \%$ by weight of total spent traction batteries. Fig. 1 presents a process flow diagram of LABs in Thailand. According to the United Nations Centre for Regional Development (UNCRD) report, most of the LABs were recycled by authorized waste processers. However, improper management accounted for only $16 \%$. An annual report of waste presented a proportion of legal management but did not report a proportion for each type of battery.

Thus, the proportion of imported LABs was used to estimate the amount of each type of batteries in waste management phase. The percentages of traction batteries in 2015, 2016, and 2017 were $47 \%, 48 \%$, and $36 \%$, respectively.

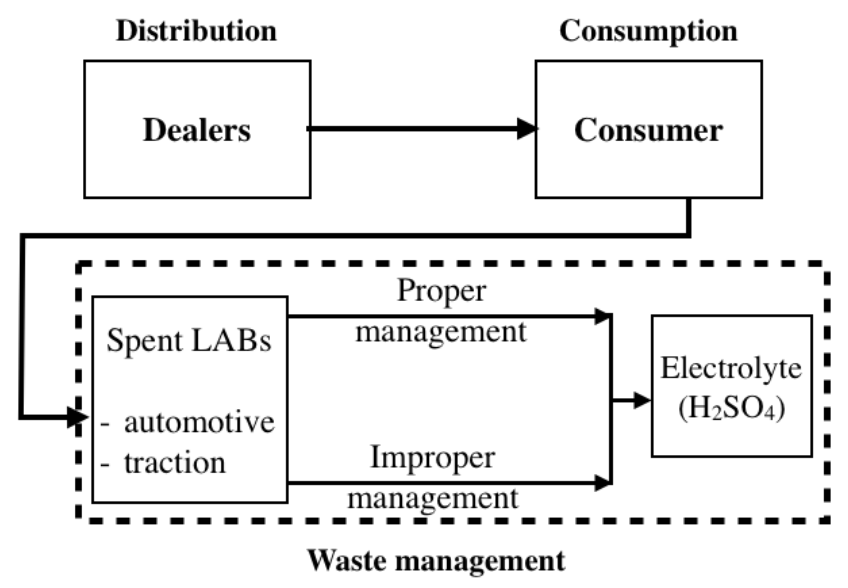

Fig. 1. Process flow diagram of lead-acid batteries. 
Fig. 2 shows the amount of spent sulfuric acid from two types of lead-acid batteries in 2015, 2016, and 2017. The results showed that the amount of spent sulfuric acid from traction batteries were lower than that from automotive batteries in 2015,2016 , and 2017. A total quantity of spent sulfuric acid that was generated in 2015, 2016, and 2017, made up 2654, 3184, and 2748 tons/year, respectively. The amounts of spent sulfuric acid from traction batteries were 1055, 1299, and 837 tons/year in 2015, 2016, and 2017, respectively. It was found that in 2017, it considerably decreased from that in 2016. In addition, the amounts of spent sulfuric acid from improper management were 425, 509, and 430 tons/year in 2015, 2016, and 2017, respectively; therefore, total amounts of spent sulfuric from traction battery and improper management were 1480, 1808, and 1267 tons/year, respectively. The highest total amount found in 2016 (1,808 tons/year) was used to environmental impact assessment.

\section{B. Environmental Impact Assessment}

The environmental impact assessment results of spent sulfuric acid from traction batteries were determined from primary data and Ecoinvent database. As calculated, the mass of six elements in the spent sulfuric acid (i.e., $\mathrm{Al}, \mathrm{Cu}, \mathrm{Fe}, \mathrm{Mg}$, $\mathrm{Pb}$, and $\mathrm{Zn}$ ) was required for the assessment process the total of spent sulfuric acid (1,808 tons), which was the amount of spent sulfuric acid from traction batteries and from improper management. For the treated acid, after $\mathrm{pH}$ adjustment water was added with an equal quantity as an input in the effluent instead of sulfuric acid.

There are 3 scenarios which were developed based on the waste treatment methods. The inputs of spent sulfuric acid for the environmental impact assessment were listed in Table I. The best case goal was to treat the total of 1,808 - ton spent sulfuric acid by $\mathrm{pH}$ adjustment. The base case was considered as a current management, which had 509.3 tons of untreated spent sulfuric acid and 1,298.8 tons of treated one. For the worst case, the total of 1,808-ton spent sulfuric acid was not treated.

As expected, the treated spent sulfuric acid had lower impact values than untreated one for all impact categories. The results of the impact assessment are summarized in Table II. It was found that the impact values increased remarkably with increasing the untreated spent sulfuric acid amount for all impact categories. A marine aquatic ecotoxicity was a major impact for all scenarios, and the impact values were $4.49 \times 10^{6}, 1.50 \times 10^{8}$, and $5.20 \times 10^{8} \mathrm{~kg} 1,4$-dichlorobenzene eq. for the best case, the base case, and the worst case, respectively. For the base and the worst cases, the marine aquatic ecotoxicity was mainly caused by sulfuric acid while the best case was mainly caused by aluminium

Due to a strong acid in the effluent, acidification was also considered as an important impact category. After the treatment, the acidification impact values dropped rapidly from $15,163.89 \mathrm{~kg} \mathrm{SO}$ eq. to 5.44 (the best case) and $4,275.14$ (the base case) $\mathrm{kg} \mathrm{SO}_{2}$ eq.

For the human toxicity potential, the base case had 100 times lower impact value than the worst case. The sulfuric acid was a major cause for the base and the worst cases while copper also was a major cause for the best case. Likewise, copper was the main factor for the best case in fresh water aquatic ecotoxicity and terrestrial ecotoxicity.

Global warming also was a remarkable impact. Its potential level for each scenario, were 935.25 (best case), $5.79 \times 10^{4}$ (the base case), $2.03 \times 10^{5}$ (the worst case) $\mathrm{kg} \mathrm{CO}_{2}$ eq. According to the literature [5], the global warming potential of $1 \mathrm{kVAh}$ LABs for the entire life was $2.63 \times 10^{5} \mathrm{~kg} \mathrm{CO}_{2}$ eq. which was comparable to the level of the worst case in this study.

Furthermore, the spent sulfuric acid had insignificant impacts on abiotic depletion, photochemical oxidation, and eutrophication potential compared to the other impact categories for all scenarios.

In summary, from this part, it is assured that treatment of spent sulfuric acid is able to mitigate environmental impacts from the spent sulfuric acid of traction batteries.

\section{Discussion}

The material flow and impact assessment of traction batteries in this study was analyzed based on secondary data and literature review. Thus, the impact assessment probably was overestimated because the maximum percentage of sulfuric acid in LABs and spent sulfuric acid quantities were used for impact calculations. In addition, it must be noted that databases in LCA software were collected from all countries in the world with uncertainty adjusted.

The MFA results provided a vast amount of spent sulfuric acid from the LABs that generated more than 2,500 tons/year. In the previous study [5], [6] showed that the major impact of LABs life cycle assessment was caused by lead smelting in regenerate phase and recycling could relieve the environmental impacts. The LCA results of 1,808-ton spent sulfuric acid provided confirmation that the all impact potentials mainly resulted from sulfuric acid.

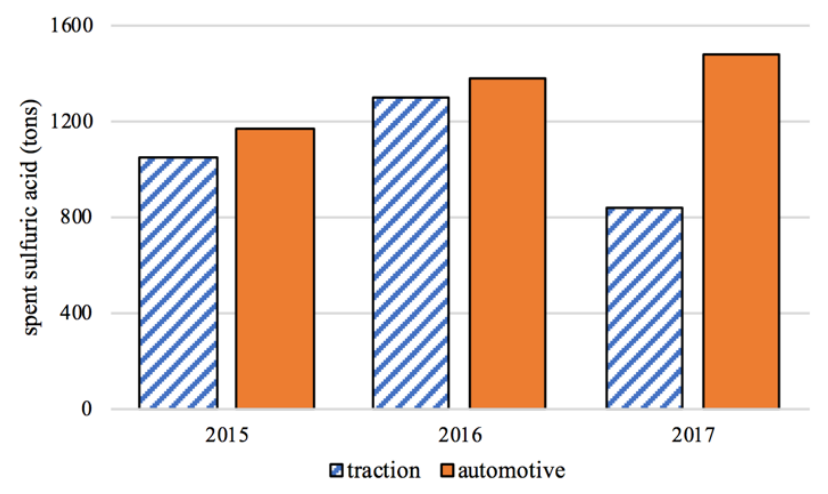

Fig. 2. The amount of spent sulfuric acid from lead-acid batteries.

TABLE I: AN INPUT OF SPENT SULFURIC ACID FOR THE ENVIRONMENTAL IMPACT ASSESSMENT

\begin{tabular}{ccc}
\hline \hline Scenarios & \multicolumn{2}{c}{ Spent sulfuric acid (tons) } \\
\cline { 2 - 3 } Best case & Untreated & $\begin{array}{c}\text { Treated by } \text { pH } \\
\text { adjustment }\end{array}$ \\
Base case & 509.3 & 1,808 \\
Worst case & 1,808 & $1,298.8$ \\
\hline \hline
\end{tabular}




\begin{tabular}{|c|c|c|c|c|}
\hline \multirow{2}{*}{ Impact category } & \multirow{2}{*}{ Unit } & \multicolumn{3}{|c|}{ Scenarios } \\
\hline & & Best case & Base case & Worst case \\
\hline Abiotic depletion & $\mathrm{kg}$ Sb eq. & 0.0614 & 1.57 & 5.40 \\
\hline Global warming & $\mathrm{kg} \mathrm{CO}_{2}$ eq. & 935.25 & $5.79 \times 10^{4}$ & $2.03 \times 10^{5}$ \\
\hline Ozone layer depletion & kg CFC-11 eq. & $7.44 \times 10^{-5}$ & 0.0357 & 0.127 \\
\hline Human toxicity & kg 1,4-DB eq. & $1,410.97$ & $9.79 \times 10^{4}$ & $3.44 \times 10^{5}$ \\
\hline Fresh water aquatic ecotoxicity & kg 1,4-DB eq. & 636.49 & $4.19 \times 10^{4}$ & $1.47 \times 10^{5}$ \\
\hline Marine aquatic ecotoxicity & kg 1,4-DB eq. & $4.49 \times 10^{6}$ & $1.50 \times 10^{8}$ & $5.20 \times 10^{8}$ \\
\hline Terrestrial ecotoxicity & kg 1,4-DB eq. & 3.45 & 225.80 & 792.85 \\
\hline Photochemical oxidation & $\mathrm{kg} \mathrm{C}_{2} \mathrm{H}_{4}$ eq. & 0.291 & 173.85 & 616.46 \\
\hline Acidification & $\mathrm{kg} \mathrm{SO}_{2}$ eq. & 5.44 & $4,275.14$ & $15,163.89$ \\
\hline Eutrophication & $\mathrm{kg} \mathrm{PO}_{4}$-eq. & 2.31 & 202.82 & 714.19 \\
\hline
\end{tabular}

Overall, the best case improved all impacts and the worst case caused the highest potential environmental issues of spent sulfuric acid management for all impact categories. The marine aquatic ecotoxicity was a major impact which strongly correlated to not only sulfuric acid but also aluminium and copper portion in spent sulfuric acid.

\section{CONCLUSION}

This study applied material flow analysis and life cycle assessment as tools to determine the environmental impacts of the spent sulfuric acid from traction battery in Thailand and compare waste management scenarios with 10 impact categories. Comparative environmental impact assessment of the 3 scenarios showed that the level of all impacts increased with the amount of sulfuric acid in the effluent. Therefore, sulfuric acid played an important role for all impact categories Treatment by $\mathrm{pH}$ adjustment of spent sulfuric acid could reduce the impact potentials, leading to the suggestion to improve and promote recycling of spent sulfuric acid management.

\section{CONFLICT OF INTEREST}

The authors declare no conflict of interest

\section{AUTHOR CONTRIBUTIONS}

Kanokporn intang conducted the research; Chodchanok Atthaphong, Sutha Khodhiar analyzed the data; Kanokporn Intang, Chodchanok Atthaphong wrote the paper; Chodchanok Atthaphong, Sutha Khodhiar revised paper; all authors had approved the final version.

\section{REFERENCES}

[1] United Nations Centre for Regional Development (UNCRD), State of the 3Rs in Asia and the Pacific: The Kingdom of Thailand, Japan: Institute for Global Environmental Strategies (IGES), 2017.
[2] R. D. Prengaman and A. H. Mirza, "Recycling concepts for lead-acid batteries," Lead-Acid Batteries for Future Automobiles, pp. 575-598, Amsterdam: Elsevier, 2017.

[3] P. H. Brunner and H. Rechberger, Handbook of Material Flow Analysis: For Environmental, Resource, and Waste Engineers, Boca Raton, FL: CRC press, 2016

[4] H. Hischier, R. Wäger, and J. Gauglhofer, "Does WEEE recycling make sense from an environmental perspective? The environmental impacts of the Swiss take-back and recycling systems for waste electrical and electronic equipment (WEEE)," Environmental Impact Assessment Review, vol. 25, pp. 525-539, 2005.

[5] W. Yu, "LCA/LCC analysis of starting-lighting-ignition lead-acid battery in China," Peer J, vol. 6, pp. 5238-5254, 2018.

[6] Q. Wang et al., "Environmental impact analysis and process optimization of batteries based on life cycle assessment," Journal of Cleaner Production, vol. 174, pp. 1262-1273, 2018.

Copyright $\odot 2019$ by the authors. This is an open access article distributed under the Creative Commons Attribution License which permits unrestricted use, distribution, and reproduction in any medium, provided the original work is properly cited (CC BY 4.0).

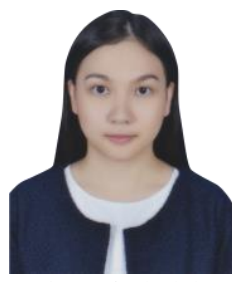

Kanokporn Intang was born in Bangkok, Thailand. She is the master degree student at Chulalongkorn University, 2018-present, Faculty of Engineering and the bachelor degree in environmental science, Chulalongkorn University, Bangkok, Thailand.

In 2017, She was internship's student at PTT Global Chemical Public Company Limited (PTTGC), Thailand and participated in environmental learning project of Chulalongkorn University.

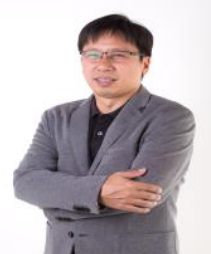

Sutha Khaodhiar received the Ph.D. in environmental engineering, Oregon State University, 1997. He is working at Department of Environmental Engineering, Faculty of Engineering, Chulalongkorn University and the director at Center of Excellence on Hazardous Substance Management, Chulalongkorn University.

Assoc. Prof. Khaodhiar's project related to the article: Life cycle assessment of palm oil microemulsion-based biofuel, Enhancement of Styrene Adsolubilization and Solubilization by Rhamnolipid Biosurfactant-Linker Mixtures onto an Aluminum Oxide Surface, and Study of Hydrophobic VOCs Absorption Mechanism in a Bubble Column: Bubble Hydrodynamic Parameters and Mass Transfer Coefficient. 
Chodchanok Attaphong received the Ph.D. in environmental engineering, the University of Oklahoma, 2014, the M.Sc. in environmental management, Chulalongkorn University, Thailand, 2007, and the B.Eng. in environmental engineering, Chulalongkorn University, Thailand, 2005.

She is working at the Department of Civil Engineering, Faculty of Engineering, King Mongkut's Institute of Technology Ladkrabang (KMITL), Thailand.

Asst. Prof. Attaphong's project related to the article: Optimized Microemulsion Systems for Detergency of Vegetable Oils at Low Surfactant
Concentration and Bath Temperature, Phase Behaviors, Fuel Properties, and Combustion Characteristics of Alcohol-vegetable oil-diesel Microemulsion Fuels, Detergency of Vegetable Oil and Semi-Solid Fats Using Microemulsion Mixtures of Anionic Extended Surfactants: The HLD Concept and Cold Water Applications, and Ethanol-in-palm oil/diesel microemulsion-based biofuel: Phase behavior, viscosity, and droplet size. 